\title{
CLINICAL APPLICATION OF GENE MEDICINE IN PREVENTING SPORTS INJURIES
}

\author{
APLICAÇÃO CLÍNICA DA MEDICINA GENÉTICA NA PREVENÇÃO DE LESÕES ESPORTIVAS
}

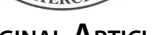

APLICACIÓN CLÍNICA DE LA MEDICINA GENÉTICA EN LA PREVENCIÓN DE LESIONES DEPORTIVAS

Original Article

ARTIGO ORIGINAL

Artículo Original

\author{
Junbo Luo' (iD \\ (Physical Education Professional) \\ Xuejun $\mathrm{Li}^{2}$ (iD) \\ (Physician) \\ 1. Hunan University of Science and \\ Engineering, College of Physical \\ Education, Yong Zhou, HuNan, \\ China. \\ 2. Central South University, Sports \\ Department of P.E, Changsha, \\ China.
}

\section{Correspondence:}

Junbo Luo

Yong Zhou, HuNan, China, 425100.

luojunbo1_3@163.com

\begin{abstract}
Introduction: Using gene therapy to transfer specific genes to implant therapeutic proteins into damaged tissues is a more promising way to treat sports injuries. The combination of tissue engineering and gene therapy will potentially promote the regeneration and repair of various damaged tissues. Objective: This article explores the adaptive relationship between gene selection therapy and athletes in sports. Methods: We selected students of related majors in sports schools to conduct specific genetic testing and measure the muscle area, fatigue level, muscle damage, and other related indicators before and after exercise. Results: After a series of physical fitness assessments, an increase in the gene sequence, as well as changes in the biochemical indices, were confirmed Conclusion: The muscle gain of the test subject during training is better than other genotypes. Level of evidence Il; Therapeutic studies - investigation of treatment results.
\end{abstract}

Keywords: Sports; Muscular fatigue; Sports injuries; Genotype profile.

\section{RESUMO}

Introdução: A terapia gênica para transferir genes específicos para codificar proteínas terapêuticas para tecidos danificados é uma forma bastante promissora de tratar lesões esportivas. A combinação de engenharia de tecidos e terapia gênica possivelmente promoverá regeneração e reparo de vários tecidos danificados. Objetivo: Este artigo explora a relação adaptativa entre a terapia de seleção gênica e atletas no esporte. Métodos: Selecionamos alunos universitários nas escolas de esportes para realizar testes genéticos especificos emedir a área muscular, nivel de fadiga, lesões musculares e outros indicadores relacionados antes e depois do exercício. Resultados: Depois de uma série de avaliações da aptidão física, verificou-se aumento da sequência gênica, assim como índices bioquímicos também apresentaram alterações. Conclusões: O ganho muscular dos indivíduos testados durante o treinamento é melhor do que outros genótipos. Nível de Evidência ll; Estudos terapêuticos - Investigação dos resultados do tratamento.

Descritores: Esportes; Fadiga muscular; Traumatismos em atletas; Perfil genético.

\section{RESUMEN}

Introducción: La terapia génica para transferir genes específicos que codifiquen proteínas terapéuticas a los tejidos dañados es una forma muy prometedora de tratar las lesiones deportivas. La combinación de ingeniería tisular y terapia génica posiblemente favorecerá la regeneración y reparación de diversos tejidos dañados. Objetivo: Este artículo explora la relación adaptativa entre la terapia de selección génica y los atletas en el deporte. Métodos: Se seleccionaron estudiantes universitarios de escuelas deportivas para realizar pruebas genéticas especificas y medir el área muscular, el nivel de fatiga, las lesiones musculares y otros indicadores relacionados antes y después del ejercicio. Resultados: Tras una serie de evaluaciones de acondicionamiento físico, se comprobó un aumento de la secuencia génica, y los índices bioquímicos también presentaron cambios. Conclusiones: El aumento de la masa muscular de los individuos analizados durante el entrenamiento es mejor que el de otros genotipos. Nivel de Evidencia ll; Estudios terapéuticos - Investigación de los resultados del tratamiento.

Descriptores: Deportes; Fatiga muscular; Traumatismos en atletas; Perfil genético.

\section{INTRODUCTION}

When the human body undergoes physical training, the motion system changes to adapt to the change in exercise volume, including the increase in vital capacity and cardiac output function. But more important is the development of muscle tissue, the thickening of muscle fibers, and the change of muscle cross-sectional area. Participants have different adaptability to the same training, which is reflected in the varying levels of anti-fatigue and anti-injury. ${ }^{1}$ CNTF encoding gene is one of the genes related to exercise ability that has been discovered. This study tested the professional training process and observed the changes in the cross-sectional area of the biceps.
Biochemical index testing covers blood lactic acid (BLA), blood urea nitrogen (BUN), serum creatine kinase (CK) value, myoglobin (Mb), etc. At the same time, we also need to analyze the adaptability of muscle tissue of different CNTF genotypes to physical training during training.

\section{METHOD \\ Object}

We selected 2152020 students from a sports major in a school. These students are all newly trained healthy men of Chinese Han nationality. The age range is $(18.2 \pm 0.7)$ years, the height range is $(170.7 \pm 7.8) \mathrm{cm}$, 
and the weight range is $(64.3 \pm 7.5) \mathrm{kg}$. Both of his parents, ancestors, and parents are of Han nationality. The volunteers had no regular training history before, so the difference in the initial training level caused by this was ruled out. All study subjects gave informed consent. ${ }^{2}$ The total training time is 11 weeks. The same unit randomly selected forty students majoring in physical education for the second year or above as the control group. The control group's height interval is (169.3 \pm 9.8$)$ $\mathrm{cm}$, and the weight interval is $(62.1 \pm 5.4) \mathrm{kg}$.

\section{Method}

All subjects used GEPR03000 B-ultrasound to measure the cross-sectional area of the biceps at the entrance physical examination. The B-ultrasonic machine's system software calculates the cross-sectional area. We used a tape measure to measure the maximum circumference of the upper arm of the subject's habitual side. ${ }^{3}$ We made a mark at the measurement site and measured the distance from the mark to the humeral ankle when the elbow was $90^{\circ}$. After obtaining a stable B-ultrasound image, record the vertical distance between the B-ultrasound probe and the mark and the relative angle between the probe and the ruler. The second measurement is performed according to the recorded coordinate axis to minimize the measurement error. A physical fitness assessment will be conducted once a week after the start of the new training. The content is carried out following the subjects specified in the training plan of the unit. The CNTF genotype of the test subject was determined by enzyme digestion with sodium citrate anticoagulant specimens. Unit code + UC/CD + sample number is used for the number of test objects.

We took $2 \mathrm{ml}$ of blood from the median cubital vein of the subject and used heparin for anticoagulation. The specimens are used to determine the value of whole blood lactic acid (BLA), serum creatine kinase (CK), serum lactate dehydrogenase (LDH), and blood myoglobin. ${ }^{4}$ We put the centrifuge tube in an appropriate centrifuge, centrifuge at 3000r/ min for 10 minutes, and carefully aspirate the supernatant. After that, we transfer it into a $5 \mathrm{ml}$ sterile centrifuge tube or desiccant tube. Serum samples are stored at $-70^{\circ} \mathrm{C}$. The cell pellet in the centrifuge tube is used to extract DNA in the next step. We used the enzyme digestion method to determine the genotype of rs2515362 locus of each test object and used the sequencing method to measure ten samples randomly. Finally, we verify the measurement results.

We performed the physical fitness test again at the same venue one week before the professional sub-training. We measured the cross-sectional area of the biceps brachii muscle and the total blood lactate, serum CK, $\mathrm{LDH}$, urea nitrogen (BUN), and myoglobin values. ${ }^{5}$ The experiment takes the average of the two measurements and analyzes the detection data.

\section{Modeling and Simulation of Muscle Biomechanics}

$X_{K}$ represents the ratio of exercise to rest time during training. $\lambda$ represents the time interval of football training. $\wp_{\beta}$ represents the muscle system. Then use formula (1) to give the characteristics of muscle changes in the training state from different angles

$$
Q(\aleph)=\frac{\widetilde{J}_{\beta}}{\lambda \times X_{K}} \otimes \frac{M(S) \oplus \imath(H)}{\sigma \cdot \mu} \cdot C
$$

$X_{K}$ represents the biomechanical parameters of muscle flexion after training. $M(S)$ represents the mechanical parameters of the maximum load of muscle after training. ${ }_{l}(H)$ represents the musculature in muscle fibers. $\sigma$ represents the steady-state contraction power of muscle fibers produced in different training stages. $\gamma$ represents the degree of muscle activation. ${ }^{6} \mathrm{C}$ represents the change in muscle density before and after training. $g$ represents the maximum load range of the muscles before training. $o(j)$ represents the length of the muscle fiber at the moment. $W(L)$ represents the degree of muscle activation after training. $\delta$ represents the physiological structure of human muscles. Then use formula (2) to give the main factors that affect the muscles of training:

$$
\beta(k, o)=\frac{g \times o(j)}{W(L) \times \delta} \times \frac{M(H) \times E(j) \times F(\delta)}{P \times \mathfrak{I}\left(\chi^{*} \beta\right)}
$$

$M(H)$ represents the direction of the tension line of the active muscle. $E(j)$ represents the transfer function of the change of $\mathrm{Ca} 2+$ concentration in the musculature. $F(\delta)$ represents the musculoskeletal movement state in different training stages. ${ }^{7} P$ represents the characteristics of the muscle contraction mechanism. $\chi$ represents the maximum muscle strength at the optimum length. $\beta$ stands for muscle microstructure. $Q$ represents the sum of the strength of all muscle fibers of the muscle. $C(L)$ represents the biochemical factors that limit muscle strength. Then use equations (3) and (4) to calculate the average muscle work and muscle torque at different training stages

$$
\begin{aligned}
& S_{(U)}=\frac{W(\beta) \otimes \frac{Q}{C(L)} \otimes T(M, N) \otimes \ell(K, M)}{Q(\aleph) \times \beta(k, o)} \\
& S_{(P)}=\frac{W(B) \otimes \frac{Q}{C(L)} \otimes T(M, N) \otimes \ell(K, M)}{Q(\aleph) \times \beta(k, o)} \otimes S_{(U)}
\end{aligned}
$$

$W(B)$ and $W(\beta)$ represent muscle fatigue work and fatigue muscle strength under football training. $T(M, N)$ and $\ell(K, M)$ represent the reaction of the motor unit when the training resistance load is small or large, respectively. $Q(\aleph)$ represents the adaptability of bone tissue to the stimulation of high-intensity training. $\beta(k, o)$ represents the relationship between surface EMG signal and muscle strength. Based on the above description, we use formula (5) to give athletes muscle biomechanical system operation principle under sports training

$$
\omega\left(m^{\prime \prime} u\right)=\frac{Q(\aleph)}{\beta(k, o) \times S_{(U)}} S_{(P)} \otimes[R(\lambda) \cdot E(K)]
$$

$R(\lambda)$ represents the relationship between the contractile force of the bone and the frequency of action potential excitation under different loads. $E(K)$ represents the dynamic contraction power of muscle fibers with varying degrees of training load.

\section{Statistical processing}

We use the SPSS18.0 software package for statistical processing. We use the $\times 2$ test for the distribution of genotypes in each group. ${ }^{8}$ We used a one-way analysis of variance and an LSD t-test of multi-sample means to analyze the relationship between each genotype and performance. $\mathrm{P}<0.05$ indicates that the difference is statistically significant.

\section{RESULTS}

The three genotypes GAIGGIAA at rs2515362 polymorphic locus of 215 athletes. The distribution of gene sequences in the test subjects was $42.8 \%, 48.4 \%$, and $8.8 \%$, respectively. ${ }^{9}$ The distribution of the three genotypes passed the Hardy Weinberg balance test $(P>0.05)$ and reached genetic balance. 
After the training process, the cross-sectional area of the biceps brachii muscle of each group of test subjects changed significantly. The $G G$ type was significantly larger than the $G A$ and $A A$ types $(P<0.05)$ (Figure 1, Figure 2, Table 1).

After the two assessments, the blood serum indicators of the test subjects will be collected. Comparing each genotype group with the control group, the blood BLA, serum CK, and blood LDH values of the genotype test subjects after physical fitness examination were higher than those of the control group $(P<0.05)$. The genotype GA/AA test subjects increased more than the GG group $(P<0.05)$. The blood BLA and serum CK values of each genotype were higher than normal values. The blood LDH value is within the normal range. ${ }^{10}$ The genotypes of serum $\mathrm{Mb}$ and $\mathrm{BUN}$ were higher than those of the control group $(P<0.05)$, but the differences between the genotypes were not statistically significant ( $>0.05)$ (Table 2).

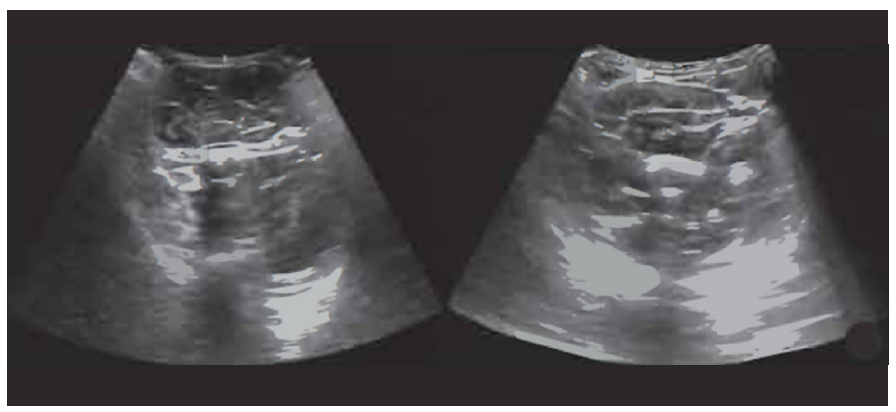

Figure 1. Biceps image before training.

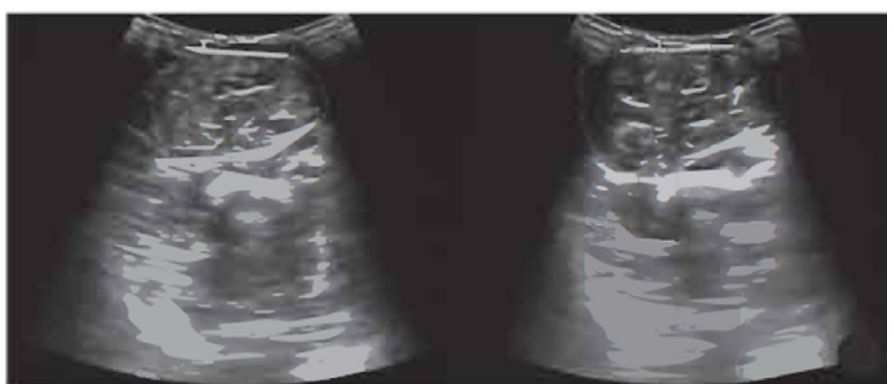

Figure 2. Biceps image after training.

Table 1. Comparison of the cross-sectional area of biceps before and after training.

\begin{tabular}{c|c|c|c|c}
\hline Group & Number of cases & Before training & After training & Value Added \\
\hline GG type & 104 & $15.1 \pm 0.2$ & $16.3 \pm 0.2$ & $1.1 \pm 0.1$ \\
\hline GA type & 19 & $15.2 \pm 0.2$ & $15.8 \pm 0.2$ & $0.7 \pm 0.2$ \\
\hline Type AA & 92 & $15.0 \pm 0.2$ & $15.8 \pm 0.2$ & $0.7 \pm 0.2$ \\
\hline F & & 2.223 & 10.175 & 8.823 \\
\hline P & & $>0.05$ & $<0.05$ & $<0.05$ \\
\hline
\end{tabular}

Table 2. The value of each detection index for changes in the serum index of the test object.

\begin{tabular}{c|c|c|c|c|c|c}
\hline Group & $\mathbf{n}$ & $\mathbf{C K}(\mathbf{U})$ & $\mathbf{L O H}(\mathbf{U})$ & $\mathbf{M b}(\mathbf{U})$ & $\begin{array}{c}\text { BLA } \\
(\mathbf{m m o l} / \mathrm{L})\end{array}$ & $\begin{array}{c}\text { BUN } \\
(\mathbf{m m o l} / L)\end{array}$ \\
\hline GG type & 104 & $271.5 \pm 98.7$ & $234.7 \pm 57.5$ & $126.0 \pm 25.1$ & $3.7 \pm 0.3$ & $5.8 \pm 0.8$ \\
\hline Type AA & 19 & $365.8 \pm 76.7$ & $284.4 \pm 68.7$ & $156.0 \pm 44.0$ & $5.8 \pm 0.7$ & $5.2 \pm 0.8$ \\
\hline GA type & 92 & $372.8 \pm 62.6$ & $232.5 \pm 45.7$ & $161 \pm 47.2$ & $5.2 \pm 0.6$ & $5.5 \pm 0.6$ \\
\hline Control group & 40 & $59.2 \pm 35.6$ & $84.7 \pm 24.7$ & $61.0 \pm 17.2$ & $1.2 \pm 0.3$ & $4.3 \pm 0.6$ \\
\hline F value & & 7.223 & 1.175 & 13.72 & 7.912 & 0.997 \\
\hline P value & & $<0.05$ & $>0.05$ & $<0.05$ & $<0.05$ & $>0.05$ \\
\hline
\end{tabular}

\section{DISCUSSION}

CNTF gene is a gene encoding CNTF factor (ciliary muscle neurotrophic factor). The exogenous CNTF factor can promote the repair of damaged motor nerves and significantly restore the motor function of the limbs. At present, it has been found that the physical fitness of the human body is closely related to heredity. Foreign studies have found that the CNTF gene may be closely related to exercise ability. In particular, there is a correlation between muscle strength and the CNTF gene. Animal tests have shown that the CNTF factor is synergistic with other neurotrophic factors, promoting motor and sensory neurons development. These gene sequences can improve animal locomotion. Enlarging exercise equipment can stimulate the CNTF gene in animals to increase the expression level in some organs to adapt to the state of exercise. Injection of human CNTF gene cloned products into animals can significantly control the weight of rats and reduce the degree of obesity in rats. ${ }^{11}$ The muscle power of the GA genotype is greater than that of the GG genotype. This suggests that people with different CNTF genotypes may have different final effects after the same training. Different genotypes may behave differently during training.

We adapt to the B-ultrasound to measure the cross-sectional area of the biceps and found that there are large differences between individuals. The elbow joint flexion and extension angles are measured at the maximum contraction of the biceps brachii. The measurement error is minimized. The measurement after the training is recorded according to the coordinate value of the first measurement of the instrument is the same measurement section. This can better reflect the changes in muscle shape in the same position.

After the new training process, the biceps morphology of all test subjects changed, especially the increase in muscle fiber thickness caused the increase in muscle volume. The increase in cross-sectional area of GG-type biceps brachii in the test subjects was better than that of other genotypes. This shows that the muscle tissue of the GG-type test object responds to the external environment caused by strength training under the stimulation of training factors. This can also prove that the ability to change the form to adapt to the environment is better.

Athletes training on the same campus is in the same environment. After eliminating the interference of diet and work and rest conditions, during the new training process, due to the new physical training, the training subjects have poor physical coordination. Due to muscle damage during training, newly trained athletes' serum CK and LDH levels increased significantly after the physical fitness assessment. Compared with students who did not participate in the assessment, the comparison is more obvious. The GG type detection object's increased value is smaller than that of the other groups of detection objects. This shows that the GG-type test subject has a lower risk of muscle damage during training.

\section{CONCLUSION}

In summary, the CNTF genotype polymorphism is related to the training adaptability of athletes' muscle tissue. The GG-type test object has better muscle gain during training than other genotypes. It is less troubled by muscle damage and has a strong anti-fatigue ability. So, they can continue to participate in training. The training process of the same intensity is less likely to stop training due to injury, and the training state is better.

All authors declare no potential conflict of interest related to this article 


\section{REFERENCES}

1. Joyner MJ. Genetic approaches for sports performance: how far away are we. Sports Med. 2019;49(2):199-204

2. Dehtyarenko T, lagotin RS. Psycho-motility of a person in the context of its psychophysiological support and genetic determination. J Phys Educ Sport. 2019;19(3):1526-31.

3. Landen S, Voisin S, Craig JM, McGee SL, Lamon S, Eynon N. Genetic and epigenetic sex-specific adaptations to endurance exercise. Epigenetics. 2019;14(6):523-35.

4. Kasper K. Sports training principles. Curr Sports Med Rep. 2019;18(4): 95-6.

5. Kuehn BM. Genetic analysis tracks SARS-CoV-2 mutations in human hosts. Jama. 2020;323(23):2363.

6. Razvi S, Peeters R, Pearce SH. Thyroid hormone therapy for subclinical hypothyroidism. Jama. 2019;321(8): 804 .
7. Clayton EW. Be ready to talk with parents about direct-to-consumer genetic testing. JAMA Pediatr. 2020;174(2):117-8.

8. Rodas G, Osaba L, Arteta D, Pruna R, Fernández D, Lucia A. Genomic prediction of tendinopathy risk in elite team sports. Int J Sports Physiol Perform. 2019;15(4):489-95.

9. Baggish AL, Levine BD. Icarus and sports after COVID 19: too close to the sun?. Circulation. 2020;142(7): 615-7.

10. Tobert KE, Bos JM, Garmany R, Ackerman MJ. Return-to-play for athletes with long QT syndrome or genetic heart diseases predisposing to sudden death. J Am Coll Cardiol. 2021;78(6):594-604.

11. Montesano P, Mazzeo F. Sports activities in obese teenagers improve social inclusion and health. Sport Mont J.2019;17(1):55-60. 